PLANTS PEOPLE

POSSIBILITIES

\title{
Mauritius Hemp
}

Author(s): D. M.

Source: Bulletin of Miscellaneous Information (Royal Botanic Gardens, Kew), Vol. 1887, No. 3 (1887), pp. 8-10

Published by: Springer on behalf of Royal Botanic Gardens, Kew

Stable URL: http://www.jstor.org/stable/4111474

Accessed: 27-06-2016 04:10 UTC

Your use of the JSTOR archive indicates your acceptance of the Terms \& Conditions of Use, available at

http://about.jstor.org/terms

JSTOR is a not-for-profit service that helps scholars, researchers, and students discover, use, and build upon a wide range of content in a trusted digital archive. We use information technology and tools to increase productivity and facilitate new forms of scholarship. For more information about JSTOR, please contact support@jstor.org.

Royal Botanic Gardens, Kew, Springer are collaborating with JSTOR to digitize, preserve and extend access to Bulletin of Miscellaneous Information (Royal Botanic Gardens, Kew) 
" factory, while in respect of colour, lustre, and fineness of fibre, your

" sample is superior to the average Sisal hemp that comes to this

" country. The value of this article is exceptionally high at present,

" 27l. per ton in London. You will see from the statistics given in

" enclosed circular that this material is an important one and is exten-

" sively used both in England and America. It enters into competition

“ with Manila hemp and was regarded as an adulterant of the latter in

" rope; but as its price is now nearly as high as that of Manila the

" ropemakers have not the same inducements to mix the hemps."

\section{VI.-MAURITIUS HEMP.}

A hemp industry was started at the Mauritius to utilize the large number of plants of Furcraa gigantea, Vent., which had spontaneously estrablished themselves on low lying lands near the sea coast. This is one of the oldest and best known species of Furcraa, and is now universally spread throughout tropical America and also in India, Ceylon, Mauritius, and St. Helena. The trunk below the rosette of leaves reaches a height of 2 to 4 feet. The leaves are 4 to 7 feet long, 4 to 6 inches broad at the middle, unarmed, bright green and channelled down the face. The scape or terminal flowering stem reaches a height of 20 to 30 feet. Like all the other Furcreas this species produces copious oblong bulbillæ in place of or in addition to flowers, which falling take root and reproduce the plant. It has often flowered under cultivation in England; the last time at Kew being the autumn of 1874 .

A full account, with description, of the various species of Furcræa is given by Mr. J. G. Baker in Gardeners' Chronicle (1879, pp. 623, 624). Furcrea gigantea is figured in the Botanical Magazine, t. 2250: Wight Ic., tab. 2025 : Decandolle, Plantes Grasses, t. 126.

Although Furcraa gigantea, known locally as Aloës vert, is the chief fibre plant in Mauritius, there is evidence that Furcraa cubensis is also found there as well as species of Agaves such as $A$. americana and others.

Bojer (Hortus Mauritianus, p. 353) mentions the Aloës vert (Furcroa gigantea) as common in 1837, and states "Croît sur la Montagne "Langue dans les endroits vides et les basilages des habitations dans “ tous les quartiers d'île." He does not mentinn Furcraa cubensis at all, so the latter must be a later production. Plants of both species have been received at Kew from the Mauritius Botanic Gardens.

Furcraa gigantea is supposed to have been introduced from South America to Mauritius about 1790. It has evidently found a congenial home there for without any effort on the part of man it has covered waste lands and abandoned sugar estates to such an extent as to lay the foundation of a considerable fibre industry. The leaves are often 8 feet in length and from 6 to 7 inches in breadth. The pulp of the leaves when crushed gives off a strong pungent odour, and hence this species is sometimes called the foetid aloe. The juice is strongly corrosive and soon acts upon wrought iron; it is said to produce less effect on cast iron, while it is practically inoperative on brass and copper.

The plant grows in all soils and up to an elevation of $1,8 \mathrm{CO}$ feet above the level of the sea. It has, however, more generally disseminated itself on the lowlands near the coast, and on a few of the abandoned sugar estates that have became too dry for cane cultivation.

A fibre industry was started at Mauritius about 12 years ago when the wet or retting system was tried. The cut leaves were first passed through the rollers of a sugar mill and steeped in water for some days. 'The fibre was then washed and beaten out by hand in running water. 
This process was soon found unsuitable as the fibre was discoloured and rendered weak; consequently it obtained comparatively low prices. Attention was theu directed to extraction by means of gratteuse or acotching machines. Many machines have since been tried, and it is believed that the purely mechanical difficulties conneeted with cleaning the fibre have heen for the most part overcome. The amount of fibre obtained from leaves of the Aloës vert was at the rate of 3 per cent. by weight of green leaves. The yield of fibre was at the rate of about $1 \frac{1}{2}$ tons per acre. A set of six machines driven by a steam engine of 8-horse power (nominal) cleaned 1,155 ponnds of fibre per day, which is at the rate of 197 pounds for each machine per day.

At one time there were eight fibre or hemp companies formed with a total capital of Rs. 1,182,500. The total quantity of fibre exported in 1872 was 214 tons, of the value of $4,934 l$., which would be at the rate of 21l. 13s. per ton. In 1880 it had increased to 662 tons, which sold in England at 28l. to $32 l$. per ton. Some samples in 1882 sold as high as 38l. per ton. Since that time low prices have ruled, and this added to the fact that the cost of production was considerably increased tended to discourage the industry. It is evident the industry was first started to work off the leaves of self-grown plants which were ready at hand in great abundance. When these leaves were exhausted it remained either to wait until the plants were regrown or to procire supplies of leaves at increased cost from the surrounding country. This latter course being adopted at a time when the market value of fibre was low rendered the enterprise unremunerative. In the returns of 1885 we find that Mauritius hemp imported to this country amounted to 255 tons of the value of $39 l$. per ton. In Messrs. Ide and Christie's monthly circular, Dec. 1886, Mauritius hemp is quoted "in good demand" at $28 l$, per ton.

The following extracts taken from Mr. Horne's Report on the Agricultural Resources of Mauritius will sufficiently explain the circumstances under which the fibre industry was started and the causes which have operated to produce the present depression, which in the interest of the island it is hoped will be only of a temporary character :-

"The industry of extracting fibres from the leaves of the aloës vert is " by no means exhausted. There is ground for believing that it has " yet a future in Mauritius. The fall in the price of this fibre in the " European markets broke several local companies that were formed " for the working of the aloe estates. There was far too much money

" invested in them for them to pay."

"On many of the estates self-sown plants abounded in great numbers. "It was from the leaves of these that the companies made money and " paid large dividends when the price of the fibre was good. The " plants had grown naturally on the land, and their presence on it had " not cost a cent. In such cases results materially differ from those of " reaping the crops of regularly laid out plantations with low prices for " the produce. The soil and climate of the localities referred to favour " the growth of the plants in such a degree that little expense need be " incurred in introducing it to new grounds. The plant produces " plantlets in great abundance in this colony. These plantlets grow " viviparously on the parent plant, and adhere to it till they have " developed into almost perfectly formed plants. When the young “ plantlets drop from their parent they are perfectly fitted to stand by " themselves. Excepting the want of roots they are perfect. The " roots are emitted as soon as the plantlets come in contact with the " moist soil, even when they are lying on the surface of the ground. "It seems, therefore, that to increase this plant rapidly and cheaply " over a given area, due advantage should be taken of its peculiarities 
" and the facilities which it naturally affords for propagation and " increase."

At St. Helena Furcraa gigantea has been for some time under cultivation as an introduced plant. Experiments on a small scale have been carried on, and samples of fibre have appeared in the English market. (Report on Resources of the Island of St. Helena, Colonial Office, African No. 275, 1884.)

Messirs. Collyer and Co. reported in 1883 on fibre from St. Helena as follows :-

"Aloe fibre (Furcraa gigantea) St. Helena. Good length, full " strength, rather dull colour, generally well cleaned but with some " runners untouched and barky. Value 28l. to 30l. per ton. This " sumple is very different in appearance from the Furcrcea gigantea " of Mauritius, owing probably to differences of both growth and treat" ment."

While on the subject of fibre from Furcraa gigantea it may not be inappropriate to say a few words as regards the merits of another species, Furcraa cubensis. This, as already pointed out, is possibly one of the plants under the name of Cajun from which some of the Yucatan fibre is obtained.

It differs from $F$. gigantea in that it has no distinct trunk, or a very short one, below the rosette of leaves. The latter are 3 to $5 \mathrm{ft}$. long, about 5 inches broad at the middle, bright green, rigid in texture, and armed with regular, hooked, brown prickles.

It is a native of tropical America and cultivated in most tropical countries. A variety of this plant-F. cubensis, var. inermis-is figured and described in Bot. Mag., t. 6543.

In addition to flowers it produces bulbils on the flowering scape, from which the plant is readily increased. The plant is common in Jamaica, and it is said that there "would be no difficulty in establishing there a large aren under cultivation." The fibre is white, strong, and bright looking. It yields at the rate of 2.05 to 3.15 per cent. by weight of green leaf. From experiments carried on at Jamaica under a committee appointed by Government it was found that lenves of Furcraa cubensis weighing $366 \frac{1}{2}$ pounds yielded 28 pounds of green fibre, which when perfectly dry weighed $7 \frac{1}{2}$ pounds. This was at the rate of 2.05 per cent. by weight of green leaf. In the report of the Committee this plant and its fibre are described as follows :-

"Silk grass (Furcraa cubensis). Leaves 5 to 6 feet long, generally

" armed with strong prickles, but sometimes unarmed or with few

" prickles. Common in Jamaica and might be largely propagated at

" once. Value of fibre- $(a$.) $28 l$., good quality, but might be whiter ;

" (b.) fairly clean, fair colour, value about 28l. per ton; (c.) superior

" to Sisal and worth 27l. per ton. A good fibre, not quite sufficiently

" white in the centre."

The above plants constitute the chief species of Agave and Furcræa yielding commercial fibres.

It may be mentioned here that many Agaves yield fibre, but the fibre may, as in the case of the Jamaica Keratto, prove unsuitable for industrial purposes. The Brokers' Report on Keratto fibre was-"little " strength : not an even (but a curly) fibre : towy : value $12 l$. to $14 l$. " per ton."

Plants yielding true Sisal Hemp might be obtained from Yucatan in large quantities.

D. M. 